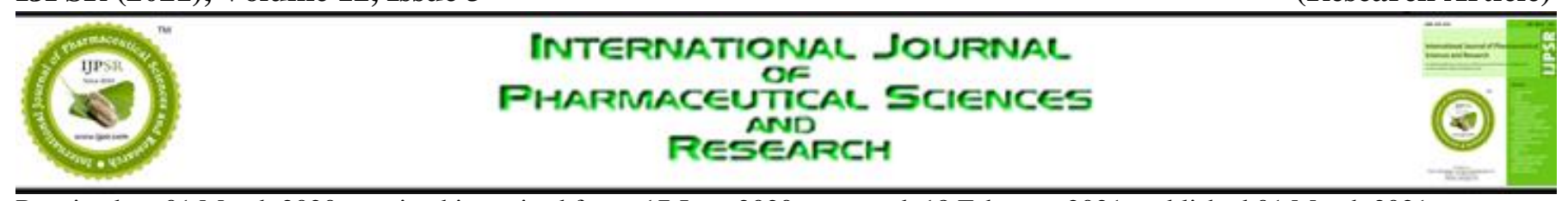

Received on 01 March 2020; received in revised form, 17 June 2020; accepted, 18 February 2021; published 01 March 2021

\title{
FORMULATION AND EVALUATION OF FLOATING MICROSPHERES OF BACLOFEN
}

\author{
Hinal Prajapati ${ }^{*}$, Keyur Patel ${ }^{2}$ and Arun Kumar Gupta ${ }^{1}$ \\ Chameli Devi Institute of Pharmacy ${ }^{1}$, Indore - 452020, Madhya Pradesh, India. \\ Kalol Institute of Pharmacy ${ }^{2}$, Kalol, Gandhinagar - 382721, Gujarat, India.
}

Keywords:

Baclofen, Floating Microspheres, Eudragit RL100, Eudragit RS100, Sustained drug delivery

\section{Correspondence to Author:}

Hinal Prajapati

Chameli Devi Institute of Pharmacy, Village Umrikheda, Khandwa Road, Indore - 452020, Madhya Pradesh, India.

E-mail: hinaldcruz@gmail.com

\begin{abstract}
The present study was aimed to formulate and evaluate floating microspheres of Baclofen. The research work's objective was to retain Baclofen in the stomach for a prolonged period of time, which has absorption window in the upper gastrointestinal tract. The microspheres were prepared by solvent evaporation technique. A $3^{2}$ full factorial was applied to investigate the combined effect of the two independent variables, i.e., the concentration of Eudragit RL100 (X1) and concentration of Eudragit RS 100 (X2) on the dependent variables particle size $\left(\mathrm{Y}_{1}\right)$, percentage drug entrapment efficiency $\left(\mathrm{Y}_{2}\right)$, percentage buoyancy (Y3), in-vitro drug release at $1 \mathrm{~h}$ (Y4), in-vitro drug release at 6 $\mathrm{h}\left(\mathrm{Y}_{5}\right)$. Results of the multiple regression analysis revealed that in-vitro drug release decreased and particle size, percentage drug entrapment efficiency, percentage buoyancy was increased with increasing the concentration of Eudragit RL100 and Eudragit RS100. The optimized formulation has a particle size of $115.96 \mu \mathrm{m}$, percentage drug entrapment of $90.06 \%$, and buoyancy of $90.76 \%$. In-vitro drug release of Baclofen floating microspheres showed a sustained release up to $24 \mathrm{~h}$. The floating microspheres were free-flowing, porous, and almost spherical in shape. The in-vitro drug release kinetics studies revealed that the Higuchi model was followed by the formulation and drug release by fickian diffusion mechanism.
\end{abstract}

INTRODUCTION: Drugs that are easily absorbed from alimentary canal (GIT) and have short halflives are eliminated quickly from the circulation. Frequent dosing of those drugs is required to realize suitable therapeutic activity. To avoid this limitation, the event of oral sustained-controlled release formulations is an effort to release the drug slowly into the alimentary canal (GIT) and maintain an efficient drug concentration in the systemic circulation for a long time ${ }^{1}$.

\begin{tabular}{|c|c|}
\hline \multirow[t]{2}{*}{ 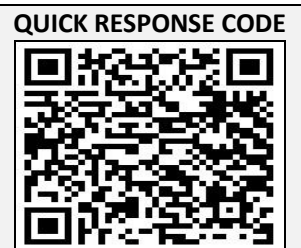 } & $\begin{array}{c}\text { DOI: } \\
\text { 10.13040/IJPSR.0975-8232.12(3).1482-94 }\end{array}$ \\
\hline & $\begin{array}{l}\text { This article can be accessed online on } \\
\qquad w w w . i j p s r . c o m\end{array}$ \\
\hline DOI link: http://dx.doi.org & 13040/IJPSR.0975-8232.12(3).1482-94 \\
\hline
\end{tabular}

Gastro retentive delivery systems are designed to be retained in the stomach for a prolonged time and release their active ingredients and thereby enable sustained and prolonged input of the drug to the upper part of the gastrointestinal (GI) tract. Gastro retentive delivery system can be classified as follows.

- Bioadhesive Drug Delivery System

- Expandable Drug Delivery System

- Floating Drug Delivery System and

- High-density systems

Among these systems, FDDS have been most commonly used. Floating drug delivery systems is one of the important approaches to achieve gastric retention to obtain sufficient drug bioavailability ${ }^{3}$. 
Floating systems are low density systems that have maximum buoyancy to float on the gastric material and remain in the stomach for longer period of time. During the system hangover the gastric contents, the drug is released sustain with desired rate, which results in elevated gastric retention time and minimizes fluctuation also ${ }^{4}$. A low amount of gastric content is required to permit the right achievement of the buoyancy retention principle, a minimal level of floating force $(\mathrm{F})$ is required to stay the dosage form buoyant on the surface of the gastric content. A floating dosage form is a feasible approach especially for drugs which have limited absorption sites in upper small intestine. The controlled, slow delivery of drug to the stomach provides sufficient local therapeutic levels and limits the systemic exposure to the drug 5

Drugs that have poor bioavailability due to site specific absorption from the upper part of the GIT are potential candidates to be formulated as floating drug delivery systems thereby increasing their absorption. Floating microspheres are gastroretentive drug delivery systems supported noneffervescent approach. Hollow microspheres are considered as one of the most promising buoyancy systems, as they possess the unique advantages of multiple unit systems as well as the better floating properties, because of the central hollow space inside the microspheres. ${ }^{6}$ These microspheres are characteristically free flowing powders consisting of proteins or synthetic polymers, ideally having a size less than 200 micrometre.

Baclofen is a gamma-aminobutyric acid (GABA) agonist used as a skeletal muscle relaxant used for the relief of painful and uncomfortable muscle spasms caused by a variety of conditions. It is known to be particularly useful in treating muscle spasticity associated with spinal cord injury. Baclofen is administered for the relief of signs and symptoms of spasticity resulting from multiple sclerosis, particularly for the relief of flexor spasms and associated pain and clonus, in addition to muscular rigidity. Baclofen has a bioavailability of $70 \%$ to $85 \%$ and is therefore rapidly absorbed through the gastrointestinal tract following oral administration. Peak plasma concentrations are generally observed 2 to 3 hours after ingestion. The absorption is dose-dependent and increases with higher doses. Baclofen is rapidly and extensively absorbed and eliminated. The half-life of the drug is $\sim 2.5$ to $4 \mathrm{hrs}$ in plasma. Baclofen has absorption window in upper Gastrointestinal (G.I.) tract. Baclofen is difficult to formulate in to sustained release dosage forms because on arrival to colon its absorption is diminished or non-existent ${ }^{7,8}$. In the present investigation efforts were made to formulate floating microspheres of Baclofen to improve the absorption of Baclofen in stomach, to prepare spherical floating microspheres, to study sustained effect of floating microspheres, to study the effect of different polymers on buoyancy and \% drug release and Statistical optimization of factorial design formulation.

\section{MATERIALS AND METHODS:}

Materials Used: Baclofen (Astron PVT. LTD. Ahmedabad), Eudragit RS 100 and Eudragit RL 100 (Yarrow Chemicals Mumbai), HPMC K4M and Magnesium stearate (Central Drug House LTD. Mumbai), Acetone (Rankem Delhi) and Light liquid paraffin and Heavy liquid paraffin(Astron chemicals India).

\section{Method:}

Drug Excipients Compatibility Study by Differential Scanning Calorimetry (DSC): Drugexcipients interactions play a vital role in the release of drug from formulation. The physiochemical compatibilities of the optimized formulations were tested by differential scanning calorimetric (DSC) analysis ${ }^{9}$. Differential Scanning Calorimetry (DSC) spectra of (i) Baclofen (ii) polymer mixture (Eudragit RS100, Eudragit RL100) (iii) Baclofen and polymer mixture (Eudragit RS100, Eudragit RL100) of all these were recorded using DSC (DCS-60, Shimadzu Corporation, Japan). Their baclofen spectra and mixture of baclofen and polymers spectra is shown in result and discussion section.

\section{Preparation of Baclofen Floating Microspheres:}

Floating microspheres loaded with baclofen were prepared by solvent evaporation technique. Firstly polymers (Eudragit RS 100, Eudragit RL100 and Hydroxy Propyl Methyl Cellulose) were dissolved in organic solvent (acetone), then drug was dispersed in polymer solution. Drug polymer solution was added drop wise using hypodermic needle in continuous phase (light liquid paraffin + 
heavy liquid paraffin). Organic solvent was evaporated due to continuous stirring using propeller mixer. After $2 \mathrm{~h}$ floating microspheres were washed with hexane several times and filtered and dried at room temperature ${ }^{10}$.

TABLE 1: COMPOSITION OF FORMULATION BATCHES

\begin{tabular}{|c|c|c|c|c|c|c|}
\hline Ingredients & Baclofen & Eudragit RL100 & Eudragit RS100 & HPMC K4M & Mg stearate & Solvent (Acetone) $(\mathrm{ml})$ \\
\hline Batches & \multicolumn{6}{|c|}{ Quantity taken (mg) } \\
\hline $\mathrm{E} 2$ & 100 & 200 & 100 & 50 & 5 & 10 \\
\hline E4 & 100 & 100 & 200 & 50 & 5 & 10 \\
\hline E5 & 100 & 200 & 200 & 50 & 5 & 10 \\
\hline E6 & 100 & 300 & 200 & 50 & 5 & 10 \\
\hline E9 & 100 & 300 & 300 & 50 & 5 & 10 \\
\hline
\end{tabular}

HPMC K4M: Hydroxymethyl Ethylcellulose

Evaluation of Baclofen Floating Microspheres:

Particle Size Analysis: Particle size analysis of drug-loaded Eudragit microspheres was performed by optical microscopy using a compound microscope. The slide containing Eudragit microspheres was mounted on the stage of the microscope and diameter of at least 300 particles was measured using a calibrated ocular micrometre. The average particle size of microspheres was determined by the total size of the microspheres divided by the number of microspheres ${ }^{11}$.

Percentage yield: The prepared microspheres were collected and weighed. The measured weight was divided by the total amount of drug and polymers which were used for the preparation of the microspheres to obtained percentage yield ${ }^{12}$. Results of percentage Yield was calculated using following equation.

$\%$ Yield $=$ Practical yield $/$ Theoretical yield $\times 100$

Percentage Drug Entrapment Efficiency: To determine the incorporation efficiency, $25 \mathrm{mg}$ microspheres were crushed and dispersed in $100 \mathrm{ml}$ $0.1 \mathrm{~N} \mathrm{HCl}$ and sonicated for 10-15 min. The dispersion was stirred on a magnetic stirrer for 24 h. The dispersion was filtered, and Drug content was analyzed Spectrophotometrically at $226.5 \mathrm{~nm}$. The percentage drug entrapment efficiency was calculated using the following equation ${ }^{13}$.

$\% \mathrm{DEE}=$ Actual drug content $/$ Theoretical drug content $\times 100$

Percentage Buoyancy Study: $100 \mathrm{mg}$ of floating microspheres were spread over the surface of a type II USP dissolution apparatus filled with $900 \mathrm{ml}$ of $0.1 \mathrm{~N} \mathrm{HCl}$. The medium was agitated with a paddle rotating at $100 \mathrm{rpm}$ for $8 \mathrm{~h}$. After $8 \mathrm{~h}$, the layer of buoyant microparticles was pipetted and separated by filtration. The particles in the sinking particulate layer were separated by filtration. Particles of both types were dried in a desiccator and weighed ${ }^{14}$. The percentage buoyancy was calculated from the weight of floating particles to the sum of floating and sinking particles.

$\%$ Buoyancy $=$ Initial weight of microspheres $/$ Weight of floating microspheres $\times 100$

In-vitro Drug Release: Percentage cumulative drug release studies were carried out for all formulations taking $20 \mathrm{mg}$ drug equivalent microspheres in USP type II dissolution test apparatus containing $900 \mathrm{ml}$ of $0.1 \mathrm{~N}$ Hydrochloric acid $(\mathrm{HCl})(\mathrm{PH} 1.2)$ maintained at $37 \pm 0.20 \mathrm{C}$ at a rotation speed of $100 \mathrm{rpm}$. The amount of the drug was determined first-derivative (D1) Spectrophotometrically at $226.5 \mathrm{~nm}$ adopting the peak height method 16 .

Residual Solvent Analysis: Residual solvent analysis was done through Gas Chromatography.

Surface Morphology Study: The surface morphology of microspheres was determined by Scanning Electron Microscopy ${ }^{17}$. Dry microspheres were placed in a scanning electron microscope brass stub and coated with gold in an ion sputter. Picture of microspheres was taken by random scanning of the stub.

Statistical Analysis: A statistical model incorporating interactive and polynomial terms was utilized to evaluate the responses. Mathematical modelling, evaluation of the ability to fit to the 
model and response surface modelling were performed by employing Design-Expert software ${ }^{18}$.

$$
\mathrm{Yi}=\mathrm{b}_{0}+\mathrm{b}_{1} \mathrm{x}_{1}+\mathrm{b}_{2} \mathrm{x}_{2}+\mathrm{b}_{12} \mathrm{x}_{1} \mathrm{x}_{2}+\mathrm{b}_{11} \mathrm{x}_{12}+\mathrm{b}_{22} \mathrm{x}_{22}
$$

Where $Y_{i}$ is the dependent variable, $b_{0}$ is the intercept (arithmetic mean response of 9 runs), $b_{1}$ to $b_{22}$ are regression coefficients, $X_{1}, X_{2}$, are the independent variables. Here the dependent variables are particle size $\left(\mathrm{Y}_{1}\right), \%$ yield $\left(\mathrm{Y}_{2}\right)$, \%drug entrapment efficiency $\left(\mathrm{Y}_{3}\right)$, \%buoyancy $\left(\mathrm{Y}_{4}\right)$, in-vitro drug release at 1 hour $\left(\mathrm{Y}_{5}\right)$, in-vitro drug release at 6 hour $\left(\mathrm{Y}_{6}\right)$ and independent variables are concentration of Eudragit RL100 (X $\left.{ }_{1}\right)$ and concentration of Eudragit $\mathrm{RS} 100\left(\mathrm{X}_{2}\right)$
Stability Study: Stability study was carried out on formulated microspheres after storing at $40{ }^{\circ} \mathrm{C}$ and $75 \%$ relative humidity for one month according to ICH guidelines ${ }^{19}$.

\section{RESULTS AND DISCUSSION:}

Drug Excipients Compatibility Study by Differential Scanning Calorimetry (DSC): In Differential Scanning Calorimetry of drug and physical mixture of drug and polymer. All peaks were not much shifted in spectra so there was no incompatibility between baclofen and polymers. It is shown in following Fig. 1, 2 and 3.

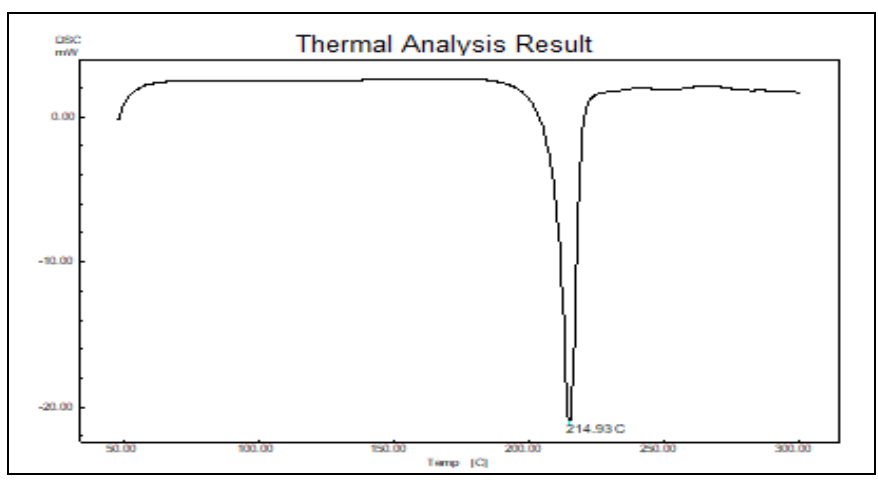

FIG. 1: DIFFERENTIAL SCANNING CALORIMETRY SPECTRA OF BACLOFEN

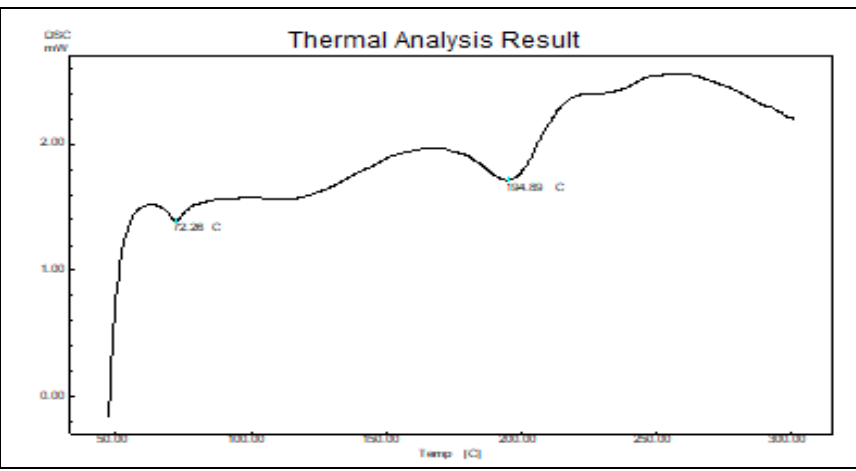

FIG. 2: DIFFERENTIAL SCANNING

CALORIMETRY SPECTRA OF POLYMER MIXTURE (EUDRAGITRL100+EUDRAGIT RS100)

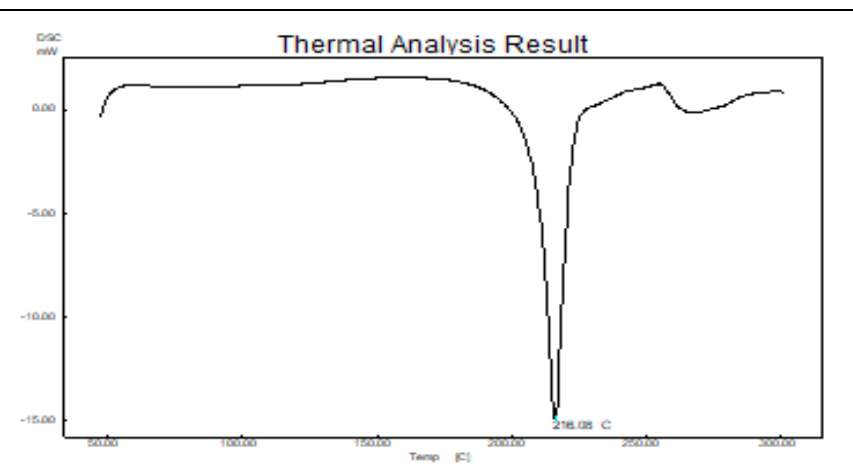

FIG. 3: DIFFERENTIAL SCANNING CALORIMETRY SPECTRA OF BACLOFEN AND POLYMER MIXTURE EUDRAGIT RL100+EUDRAGIT RS100)

using polymers. Results of baclofen floating microspheres are shown in Table 2. Floating microspheres of baclofen are showed in Fig. 4.
Results of Batches of Baclofen Floating Microspheres: Floating microspheres of baclofen were prepared by solvent evaporation technique

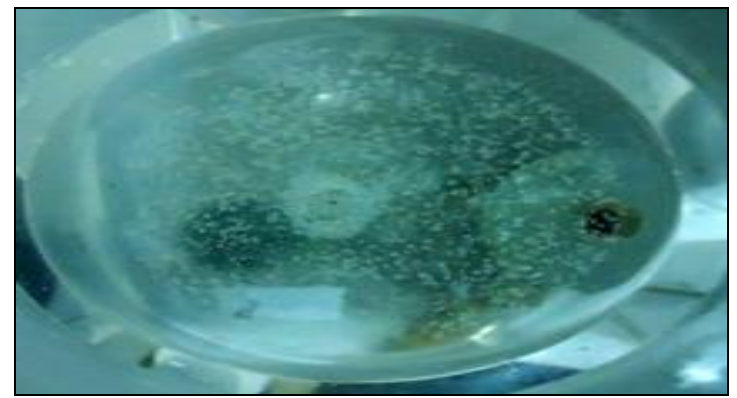


TABLE 2: PARTICLE SIZE, \% YIELD, \% DRUG ENTRAPMENT EFFICIENCY, \% BUOYANCY

\begin{tabular}{ccccc}
\hline Batch & Particle size $(\boldsymbol{\mu m})$ & Percentage yield $(\boldsymbol{\%})$ & DEE $(\boldsymbol{\%})$ & Percentage Buoyancy $(\boldsymbol{\%})$ \\
\hline E1 & $68.20 \pm 2.32$ & $52.12 \pm 1.96$ & $71.25 \pm 1.2$ & $80.60 \pm 1.2$ \\
E2 & $81.30 \pm 2.23$ & $57.23 \pm 2.24$ & $75.12 \pm 2.3$ & $83.66 \pm 1.7$ \\
E3 & $95.41 \pm 1.52$ & $65.06 \pm 2.45$ & $83.32 \pm 3.2$ & $85.12 \pm 1.2$ \\
E4 & $85.12 \pm 1.61$ & $59.02 \pm 2.47$ & $80.21 \pm 1.5$ & $85.21 \pm 1.8$ \\
E5 & $98.15 \pm 1.29$ & $67.51 \pm 2.21$ & $78.12 \pm 2.5$ & $82.16 \pm 1.5$ \\
E6 & $105.13 \pm 2.18$ & $74.22 \pm 2.52$ & $85.28 \pm 3.5$ & $88.01 \pm 2.1$ \\
E7 & $100.01 \pm 1.56$ & $67.89 \pm 2.50$ & $87.41 \pm 2.3$ & $87.50 \pm 1.6$ \\
E8 & $112.03 \pm 1.94$ & $77.91 \pm 2.55$ & $89.42 \pm 2.8$ & $90.12 \pm 1.9$ \\
E9 & $119.05 \pm 2.45$ & $85.11 \pm 3.16$ & $92.06 \pm 3.8$ & $92.21 \pm 2.5$ \\
\hline
\end{tabular}

Dee: drug entrapment efficiency

Particle Size Analysis: Floating microspheres containing baclofen was successfully prepared by "solvent evaporation" method. The average particle size Table 2 of the prepared floating microspheres was lowest for the E1 formulation $(68.2 \mu \mathrm{m})$ and was highest for $\mathrm{E} 9$ formulation $(119.05 \mu \mathrm{m})$. From the results of the particle size measurement it was concluded that as the core to coat ratio (drug to polymer ratio) increased there was an increase of the particle size. This may be attributed to the increase in the viscosity of the solution containing drug and polymer mixture, as constant amounts of the solvents were used for their solubilisation. Here Eudragit RS100 has more effect on particle size than Eudragit RL100. ${ }^{10}$

\% Yield: From Table 2, it shows that as drug: polymer ratio was increased; the \%yield was increased ${ }^{10}$.

Percentage Drug Entrapment Efficiency: The drug entrapment efficiency Table 2 was higher in E9 batch $(92.06 \%)$. The results obtained clearly indicated that the drug entrapment efficiency increased as the drug to polymer (core to coat) ratio increased. This may be attributed to the availability of more coat material per core molecule. The entrapment efficiency was also higher because the drug was present in a non-aqueous media (light liquid paraffin theavy liquid paraffin) in which the solubility of the drug is very low, thereby preventing the loss of the drug into the dispersion medium during the formulation of microspheres ${ }^{20}$.

Percentage Buoyancy: The floating ability Table 2 of E1 formulation was lowest, amounting to 80.6\% and it was highest for E9 formulation (92.21 $\%)$. The formulations prepared from more ratio of Eudragit RS100+ Eudragit RL100 polymer were found to have good floating ability than those formulated from less ratio of Eudragit RS100+ Eudragit RL100 polymer. The lower floating ability of the prepared floating microspheres may be ascribed to their small size. Here Eudragit RS100 has better floating ability as compared to Eudragit RL100 because of its low bulk density and low permeability than Eudragit RL100. As the size was small, the mass / volume ratio (density) may be more, leading to an early settling of the microspheres.

\section{In-vitro Drug Release Study:}

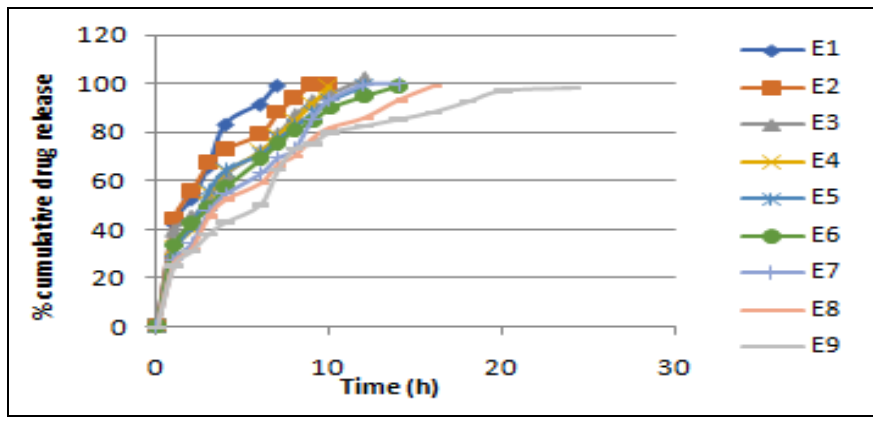

FIG. 5: IN-VITRO DRUG RELEASE PROFILE

TABLE 3: IN-VITRO DRUG RELEASE STUDY

\begin{tabular}{cccccccccc}
\hline TIME & \multicolumn{8}{c}{ Batch code } \\
\cline { 2 - 10 } (hour) & E1 & E2 & E3 & E4 & E5 & E6 & E7 & E8 & E9 \\
\hline 1 & $42.32 \pm$ & $44.41 \pm$ & $39.56 \pm$ & $32.15 \pm$ & $31.21 \pm$ & $33.56 \pm$ & $27.31 \pm$ & $26.37 \pm$ & $25.35 \pm$ \\
& 1.81 & 1.15 & 1.77 & 1.72 & 1.04 & 1.99 & 1.82 & 1.85 & 1.16 \\
2 & $52.35 \pm$ & $55.76 \pm$ & $45.23 \pm$ & $40.28 \pm$ & $41.28 \pm$ & $42.53 \pm$ & $34.23 \pm$ & $31.9 \pm$ & $31.12 \pm$ \\
& 1.05 & 1.64 & 1.09 & 1.71 & 1.96 & 1.05 & 1.90 & 1.13 & 1.08 \\
3 & $65.67 \pm$ & $68.40 \pm$ & $54.36 \pm$ & $55.16 \pm$ & $56.12 \pm$ & $49.25 \pm$ & $47.42 \pm$ & $45.35 \pm$ & $38.25 \pm$ \\
& 1.48 & 1.93 & 1.76 & 1.89 & 1.19 & 1.63 & 1.38 & 1.65 & 1.90 \\
4 & $83.33 \pm$ & $79.29 \pm$ & $63.26 \pm$ & $64.23 \pm$ & $64.56 \pm$ & $57.63 \pm$ & $54.82 \pm$ & $52.33 \pm$ & $43.21 \pm$ \\
\hline
\end{tabular}




\begin{tabular}{|c|c|c|c|c|c|c|c|c|c|}
\hline & 1.17 & 1.77 & 1.45 & 1.19 & 1.16 & 1.95 & 1.04 & 1.92 & 1.19 \\
\hline 6 & $\begin{array}{c}91.57 \pm \\
1.84\end{array}$ & $\begin{array}{c}89.49 \pm \\
1.01\end{array}$ & $\begin{array}{c}74.36 \pm \\
1.78\end{array}$ & $\begin{array}{c}72.15 \pm \\
1.69\end{array}$ & $\begin{array}{c}71.1 \pm \\
1.85\end{array}$ & $\begin{array}{c}69.12 \pm \\
1.83\end{array}$ & $\begin{array}{c}63.15 \pm \\
1.14\end{array}$ & $\begin{array}{c}58.91 \pm \\
1.95\end{array}$ & $\begin{array}{c}50.35 \pm \\
1.05\end{array}$ \\
\hline 7 & $\begin{array}{c}99.42 \pm \\
1.55\end{array}$ & $\begin{array}{c}96.20 \pm \\
1.01\end{array}$ & $\begin{array}{c}79.56 \pm \\
1.59\end{array}$ & $\begin{array}{c}79.20 \pm \\
1.95\end{array}$ & $\begin{array}{c}77.27 \pm \\
1.06\end{array}$ & $\begin{array}{c}75.69 \pm \\
1.83\end{array}$ & $\begin{array}{c}69.56 \pm \\
1.44\end{array}$ & $\begin{array}{c}66.53 \pm \\
1.56\end{array}$ & $\begin{array}{c}64.56 \pm \\
1.13\end{array}$ \\
\hline 8 & & $\begin{array}{c}100.01 \\
\pm 1.09\end{array}$ & $\begin{array}{c}87.26 \pm \\
1.14\end{array}$ & $\begin{array}{c}85.5 \pm \\
1.29\end{array}$ & $\begin{array}{c}82.26 \pm \\
1.99\end{array}$ & $\begin{array}{c}81.23 \pm \\
1.05\end{array}$ & $\begin{array}{c}73.21 \pm \\
1.02\end{array}$ & $\begin{array}{c}70.1 \pm \\
1.98\end{array}$ & $\begin{array}{c}73.45 \pm \\
1.10\end{array}$ \\
\hline 9 & & & $\begin{array}{c}93.5 \pm \\
1.89\end{array}$ & $\begin{array}{c}92.21 \pm \\
1.94\end{array}$ & $\begin{array}{c}88.15 \pm \\
1.69\end{array}$ & $\begin{array}{c}84.56 \pm \\
1.45\end{array}$ & $\begin{array}{c}85.56 \pm \\
1.45\end{array}$ & $\begin{array}{c}77.21 \pm \\
1.02\end{array}$ & $\begin{array}{c}75.21 \pm \\
1.12\end{array}$ \\
\hline 10 & & & $\begin{array}{c}96.33 \pm \\
1.17\end{array}$ & $\begin{array}{c}99.13 \pm \\
1.24\end{array}$ & $\begin{array}{c}93.6 \pm \\
1.62\end{array}$ & $\begin{array}{c}90.11 \pm \\
1.78\end{array}$ & $\begin{array}{c}93.42 \pm \\
1.64\end{array}$ & $\begin{array}{c}81.62 \pm \\
1.16\end{array}$ & $\begin{array}{c}79.85 \pm \\
1.92\end{array}$ \\
\hline 12 & & & $\begin{array}{c}102.9 \pm \\
1.26\end{array}$ & & $\begin{array}{c}99.08 \pm \\
1.09\end{array}$ & $\begin{array}{c}95.1 \pm \\
1.32\end{array}$ & $\begin{array}{c}99.56 \pm \\
1.94\end{array}$ & $\begin{array}{c}85.62 \pm \\
1.70\end{array}$ & $\begin{array}{c}82.56 \pm \\
1.14\end{array}$ \\
\hline 14 & & & & & & $\begin{array}{c}99.32 \pm \\
1.28\end{array}$ & $\begin{array}{c}100.03 \\
\pm 1.39\end{array}$ & $\begin{array}{c}92.93 \pm \\
1.97\end{array}$ & $\begin{array}{c}85.33 \pm \\
1.84\end{array}$ \\
\hline 16 & & & & & & & & $\begin{array}{c}98.63 \pm \\
1.26\end{array}$ & $\begin{array}{c}88.27 \pm \\
1.56\end{array}$ \\
\hline 18 & & & & & & & & & $\begin{array}{c}92.56 \pm \\
1.02\end{array}$ \\
\hline 20 & & & & & & & & & $\begin{array}{c}97.02 \pm \\
1.59\end{array}$ \\
\hline 24 & & & & & & & & & $\begin{array}{c}98.12 \pm \\
1.02\end{array}$ \\
\hline
\end{tabular}

*Values are expressed as mean $\pm \operatorname{SD}(n=3)$

From the Fig. 5 and Table 3, it can be seen that increased in drug: polymer ratio decreased the release rate. It was due to as increased in polymer concentration the matrix wall of microspheres became thicker with less no of pores. Here drug release pattern was initially bursting and then sustained. It was due to drug crystal might be present on surface of microspheres. It was also observed that the release rate of drug from (1:2) ratio of drug (baclofen) + polymer mixture
(Eudragit RL100, Eudragit RS 100) microspheres was a higher than that of (1:6) ratio of drug (baclofen) + polymer mixture (Eudragit RL100, Eudragit RS 100) microspheres. The thick polymeric barrier slows the entry of surrounding dissolution medium in to the microspheres and hence less quantity of drug leaches out from the polymer matrices of the microspheres exhibiting slow release ${ }^{21}$.

\section{Residual Solvent Analysis:}

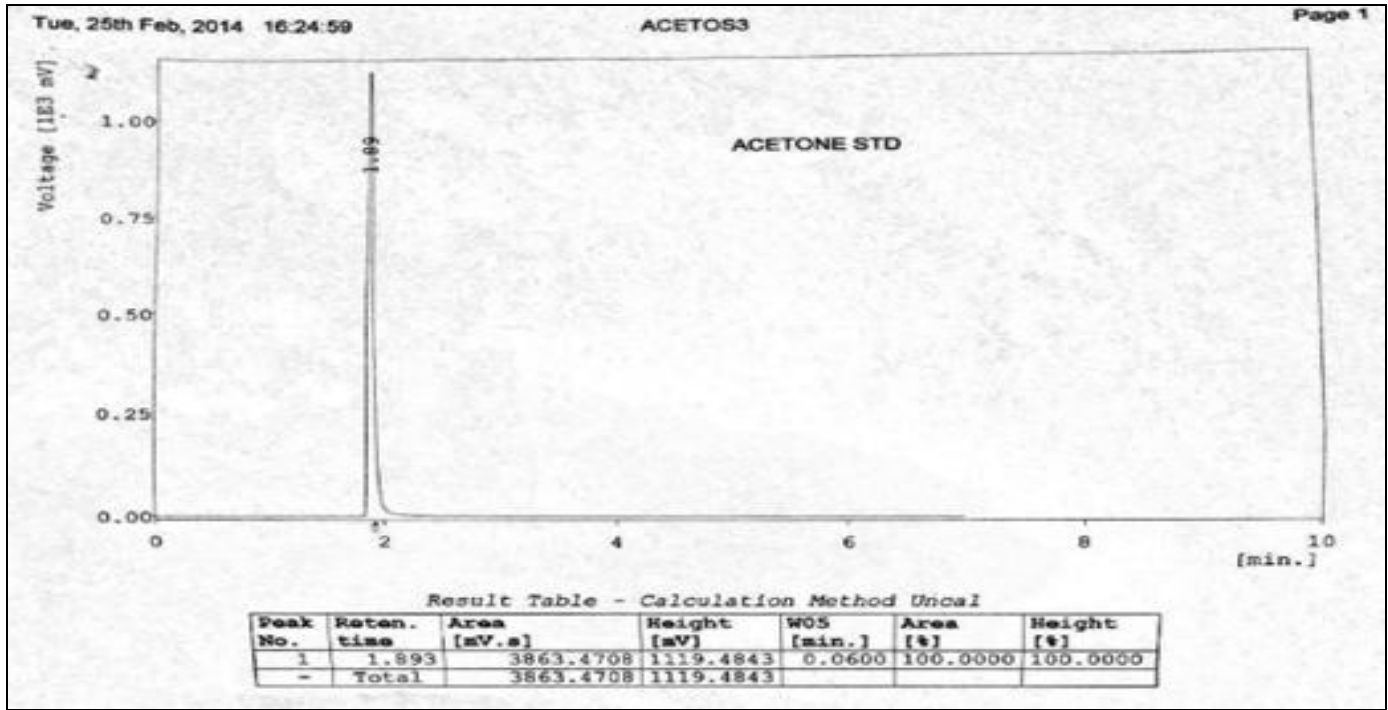

FIG. 6: GAS CHROMATOGRAPHY OF ACETONE 


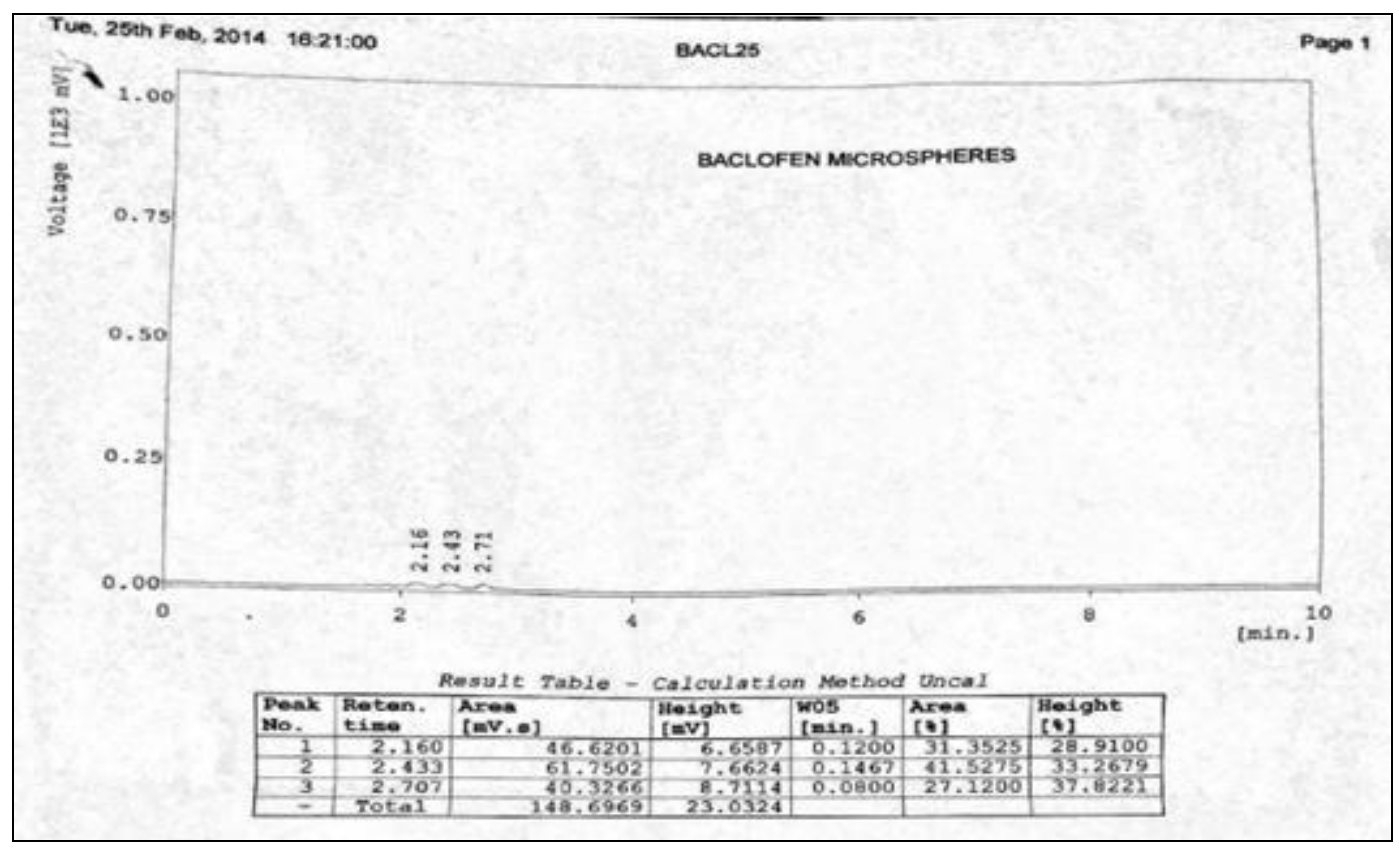

FIG. 7: GAS CHROMATOGRAPHY OF FLOATINGMICROSPHERES OF BACLOFEN

From the residual solvent analysis report it was concluded that acetone is absent in prepared floating microspheres as peak of acetone is not visible in GC of microspheres as shown in Fig. 6 and 7.

Surface Morphology Study: From scanning electron microscopy study, it is concluded that microspheres were fairly smooth and spherical in shape having porous structure.

The surface of microspheres consists of crystals of remaining drug which is responsible for initial bursting effect as shown in Fig. 8. ${ }^{10,20}$
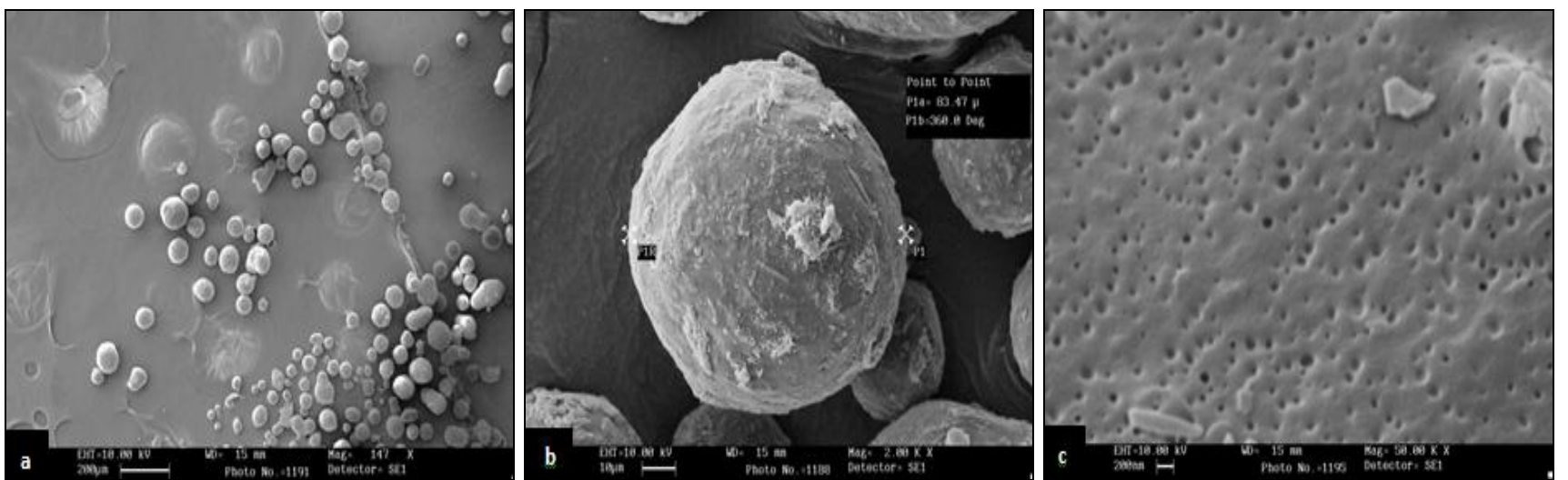

FIG. 8: SCANNING ELECTRON MICROSCOPY IMAGES: A) SPHERICAL FLOATING MICROSPHERES OF BACLOFEN B) ZOOMED VIEW OF SPHERICAL FLOATING MICROSPHERE OF BACLOFEN C) POROUS SURFACE OF FLOATING MICROSPHERE OF BACLOFEN

Statistical Analysis: Average particle size was varying from 68. 2-119.05 $\mu \mathrm{m}$ Table 2 and showed correlation 0.9955 Table 4 . The $\mathrm{p}$ values lower than 0.05 so $\times 1$ and $\times 2$ have a significant effect. $\times$ 1 (Eudrgit RL100) and $\times 2$ (Eudragit RS100) both had a positive effect. It indicates that as the drug to polymer ratio increases the particle size increases. So, both $\times 1$ and $\times 2$ significantly affect the particle size. Here $\times 2$ has more significant effect as compared to $\times 1$.
Percentage drug entrapment efficiency was varying from 71.25 - $92.06 \%$ Table 2 and showed correlation 0.9705 Table 4 . The $\mathrm{p}$ values lower than 0.05 so $X_{1}$ and $X_{2}$ have a significant effect. $X_{1}$ (Eudrgit RL 100) and $X_{2}$ (Eudragit RS100) both had a positive effect. It indicates that as the drug to polymer ratio increases, drug entrapment efficiency increases. So, both $X_{1}$ and $X_{2}$ significantly affect entrapment efficiency. Here $\mathrm{X}_{2}$ has a more significant effect as compared to $\mathrm{X}_{1}$. 
Percentage buoyancy was varying from 80.6$92.21 \%$ as shown in Table 2 and showed correlation 0.8817 in Table 4. The $\mathrm{p}$ values lower than 0.05 so $X_{1}$ and $X_{2}$ have significant effect. $X_{1}$ (Eudrgit RL 100) and $X_{2}$ (Eudragit RS 100) both had positive effect. It indicates that as the drug to polymer ratio increases buoyancy increases. So, both $\mathrm{X}_{1}$ and $\mathrm{X}_{2}$ significant affect the buoyancy. Here $\mathrm{X}_{2}$ has more significant effect as compared to $\mathrm{X}_{1}$.

In-vitro drug release at $1 \mathrm{~h}$ was varying from 42.32 $25.35 \%$ as shown in Table 3 of E1 to E9 batch and showed correlation 0.9086 in Table 4. The $p$ values lower than 0.05 so $X_{1}$ and $X_{2}$ have significant effect. $X_{1}$ (Eudrgit RL100) and $X_{2}$ (Eudragit RS 100) both had negative effect. It indicates that as the drug to polymer ratio increases, it decreases the drug release. So, both $X_{1}$ and $X_{2}$ significant affect the drug release. Here $X_{2}$ has more significant effect as compared to $X_{1}$. The $p$ value of $X_{1}$ was more than 0.05 so it was insignificant and do not affect $\%$ cumulative drug release (CDR) at $1 \mathrm{~h}$.

In-vitro drug release at $6 \mathrm{~h}$ was varying from 91.57$50.35 \%$ as shown in Table 3 of E1 to E9 batch and showed correlation 0.9271 in Table 4 . The $p$ values lower than 0.05 so they are significant effect. $\mathrm{X}_{1}$ (Eudrgit RL 100) and $\mathrm{X}_{2}$ (Eudragit RS 100) both had negative effect. It indicates that as the drug to polymer ratio increases it decreases the drug release. So, both $X_{1}$ and $X_{2}$ significant affect the dissolution. Here $X_{2}$ has more negative effect as compared to $\mathrm{X}_{1}$. The $\mathrm{p}$ value of both $\mathrm{X}_{1}$ and $\mathrm{X}_{2}$ was less than 0.05 therefore they both have significant effect.

\section{TABLE 4: REGRESSION ANALYSIS FOR EFFECT OF X1(EUDRAGIT RL100) \& X2(EUDRAGIT RS100)}

\begin{tabular}{|c|c|c|c|c|c|c|}
\hline Parameter & R Square & $\begin{array}{l}\text { Adjusted R } \\
\text { square }\end{array}$ & Observations & Source & $\begin{array}{c}\text { Sum of } \\
\text { squares }\end{array}$ & P-value \\
\hline Average particle size $\left(\mathrm{Y}_{1}\right)$ & $\begin{array}{r}\text { Full } \mathrm{m} \\
\text { Rec }\end{array}$ & $\begin{array}{l}\text { equation: } \mathbf{Y}_{\mathbf{1}} \\
\text { model equati }\end{array}$ & $\begin{array}{l}7.87+11.04 X_{1}+1 \\
Y_{1}=+97.87+11.0\end{array}$ & $\begin{array}{c}\text { Model } \\
\mathrm{X}_{1} \\
\mathrm{X}_{2} \\
\mathrm{X}_{12} \\
\mathrm{X}_{1}^{2} \\
\mathrm{X}_{2}^{2} \\
\mathbf{X}_{\mathbf{2}}-\mathbf{2 . 0 4 X} \\
\mathbf{- 1 4 . 3 7 X _ { 2 }}\end{array}$ & $\begin{array}{c}2003.21 \\
731.51 \\
1238.12 \\
16.65 \\
11.58 \\
0.71 \\
-\mathbf{2 . 0 5 X _ { 1 }}{ }^{2}-\mathbf{0} \\
\mathbf{4} \mathbf{X}_{1} \mathbf{X}_{\mathbf{2}}-\mathbf{2 . 0}\end{array}$ & $\begin{array}{l}<0.0001 \\
<0.0001 \\
<0.0001 \\
0.0089 \\
0.0202 \\
0.4825 \\
\mathbf{X}_{2}{ }^{2}\end{array}$ \\
\hline $\begin{array}{l}\% \text { drug entrapment } \\
\text { efficiency }\left(\mathrm{Y}_{2}\right)\end{array}$ & $\begin{array}{r}\text { Full } \mathrm{r} \\
\text { Reduce }\end{array}$ & $\begin{array}{l}\text { equation: } \mathbf{Y}_{2} \\
\text { del equation: }\end{array}$ & $\begin{array}{l}\text { 78.59+3.63X } \\
+78.59+3.63 X_{1}+6\end{array}$ & $\begin{array}{c}\text { Model } \\
X_{1} \\
X_{2} \\
X_{12} \\
X_{1}^{2} \\
X_{2}^{2} \\
\text { 2-1.85 } \\
\mathbf{X}_{2} \mathbf{2}-\mathbf{1 . 8 5 X}\end{array}$ & $\begin{array}{c}416.88 \\
79.13 \\
256.11 \\
13.76 \\
24.71 \\
17.48 \\
\mathbf{2 . 9 9}_{\mathbf{1}}{ }^{2}+\mathbf{2} \\
+\mathbf{2 . 9 9}^{2}\end{array}$ & $\begin{array}{c}<0.0001 \\
0.0003 \\
<0.0001 \\
0.0281 \\
0.0077 \\
0.0171 \\
2_{2}^{2} \\
2 \mathbf{X}_{2}{ }^{2}\end{array}$ \\
\hline$\%$ buoyancy $\left(\mathrm{Y}_{3}\right)$ & Full m & $\begin{array}{l}\text { equation: } \mathbf{Y}_{3} \\
\text { duced model }\end{array}$ & $\begin{array}{l}2.25+2.00 X_{1}+3 \text {. } \\
\text { tion: } Y_{3}=+82.25\end{array}$ & $\begin{array}{c}\text { Model } \\
\mathrm{X}_{1} \\
\mathrm{X}_{2} \\
\mathrm{X}_{12} \\
\mathrm{X}_{1}^{2} \\
\mathrm{X}_{2}^{2} \\
\mathbf{+ 0 . 0 4 8} \mathbf{X}_{1} \\
\mathbf{0} \mathbf{X}_{\mathbf{1}}+\mathbf{3 . 4 1}\end{array}$ & $\begin{array}{c}136.50 \\
24.12 \\
69.70 \\
9.025 \mathrm{E}- \\
003 \\
11.55 \\
14.93 \\
-\mathbf{2 . 0 4 X _ { 1 }}{ }^{2}+ \\
\mathbf{2 . 3 2}_{\mathbf{2}}{ }^{2}\end{array}$ & $\begin{array}{r}0.0038 \\
0.0189 \\
0.0013 \\
0.9548 \\
\\
0.0738 \\
0.0483 \\
\mathbf{X}_{2}{ }^{2}\end{array}$ \\
\hline $\begin{array}{l}\text { \%cumulative drug release } \\
\text { at } \mathrm{Q}_{1} \text { (in-vitro drug } \\
\text { release at } 1 \mathrm{~h})\left(\mathrm{Y}_{4}\right)\end{array}$ & 0.9086 & $\begin{array}{r}\text { Full moc } \\
\text { Reduce }\end{array}$ & $\begin{array}{l}\text { uation: } \mathbf{Y}_{\mathbf{4}}=\mathbf{+ 3 2} \\
\text { del equation: } \mathbf{Y}\end{array}$ & $\begin{array}{c}\text { Model } \\
X_{1} \\
X_{2} \\
\mathbf{0 . 5 5} \mathbf{X}_{1}-7 . \\
\mathbf{3 2 . 8 5 - 7 . 8}\end{array}$ & $\begin{array}{c}374.08 \\
1.83 \\
372.25\end{array}$ & $\begin{array}{l}<0.0001 \\
0.5020 \\
<0.0001\end{array}$ \\
\hline $\begin{array}{l}\text { \%cumulative drug release } \\
\text { at } \mathrm{Q}_{6} \text { (in-vitro drug } \\
\text { release at } 6 \mathrm{~h})\left(\mathrm{Y}_{5}\right)\end{array}$ & 0.9271 & $\begin{array}{r}\text { Full mod } \\
\text { Reduced } \mathrm{m}\end{array}$ & $\begin{array}{l}\text { uation } Y_{5}=+70 \\
\text { equation } Y_{5}=+7\end{array}$ & $\begin{array}{c}\text { Model } \\
X_{1} \\
X_{2} \\
.85 X_{1-11} \\
\mathbf{- 5 . 8 5} \mathbf{X}_{\mathbf{1}^{-}}\end{array}$ & $\begin{array}{l}1046.33 \\
205.22 \\
841.11 \\
\mathbf{X}_{2} \\
\mathbf{4 X}_{2}\end{array}$ & $\begin{array}{l}<0.0001 \\
0.0005 \\
<0.0001\end{array}$ \\
\hline
\end{tabular}




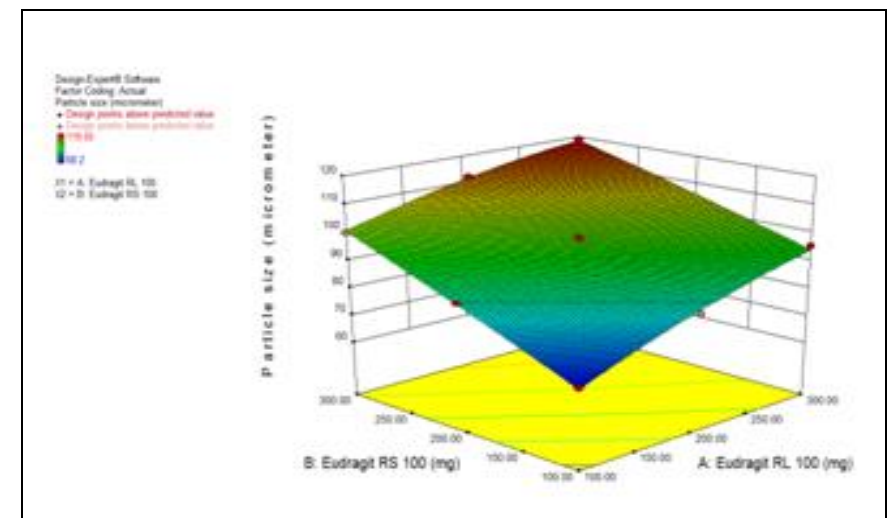

FIG. 9: 3D RESPONSE SURFACE GRAPH FOR PARTICLE SIZE

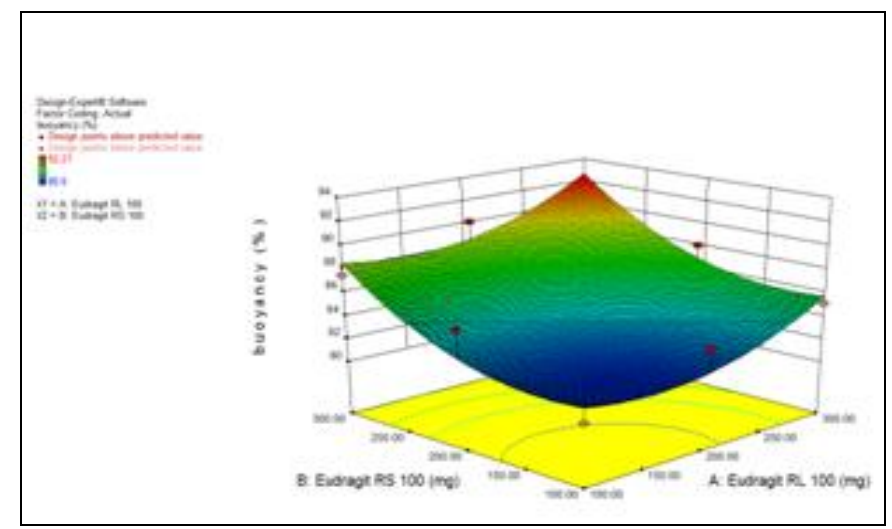

FIG. 11: 3D RESPONSE SURFACE GRAPH FOR \%BUOYANCY

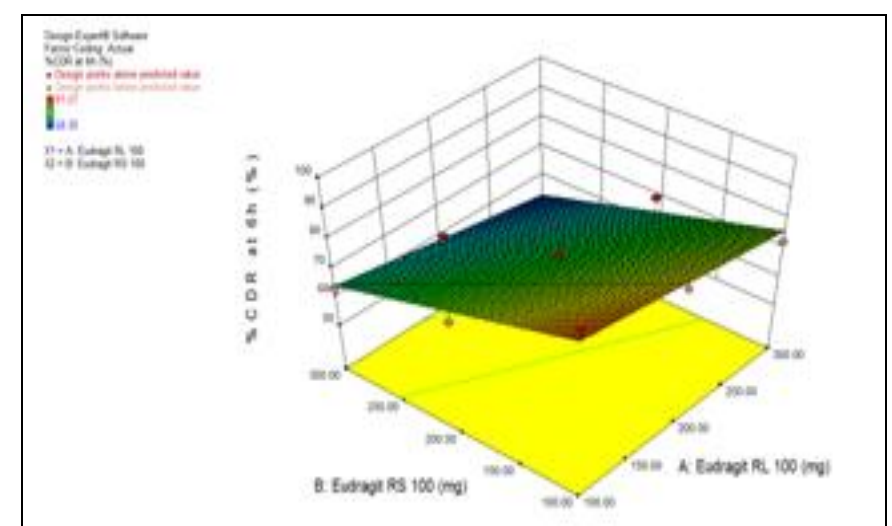

FIG. 13: 3D SURFACE RESPONSE GRAPH FOR \% CUMULATIVE DRUG RELEASE (CDR) AT $6 \mathrm{~h}$

Preparation of Check Point Batch from Overlay Plot: Checkpoint batch $\mathrm{C}_{1}$ and $\mathrm{C}_{2}$ were selected from the overlay plot of responses. The amount of Eudragit RL100 and Eudragit RS100 and according to their amounts, the predicted responses were given in the Overlay plot flag or in the solution of overlay data. From that, any two batches $\mathrm{C}_{1}$ and $\mathrm{C}_{2}$ were selected for the verification of the model.

Following Table 5 is showing the formula for $\mathrm{C}_{1}$ and $\mathrm{C}_{2}$ batches:

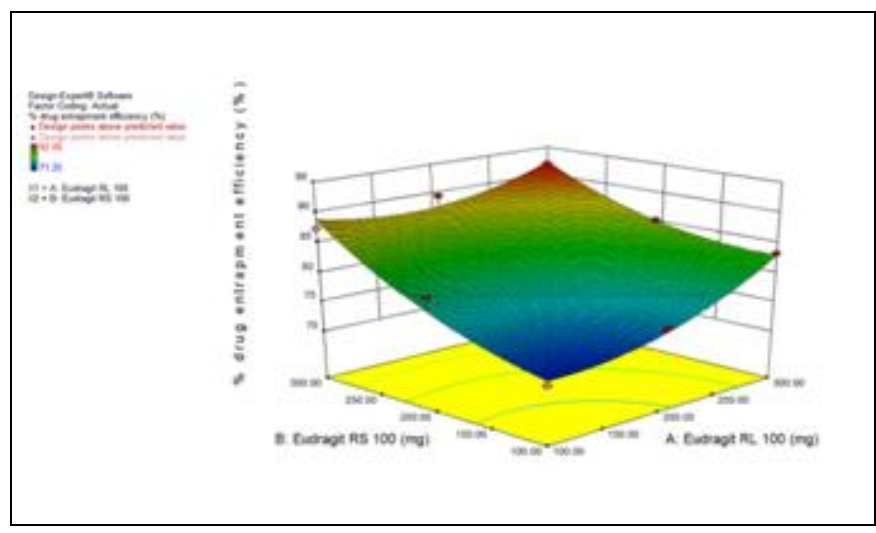

FIG 10: 3D RESPONSE SURFACE GRAPH FOR DRUG ENTRAPMENT

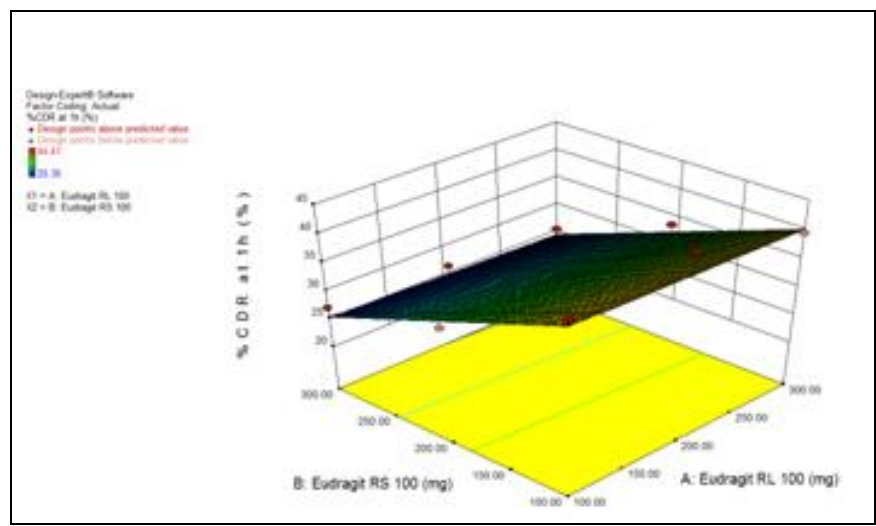

FIG. 12: 3D RESPONSE SURFACE GRAPH FOR \% CUMULATIVE DRUG RELEASE (CDR) AT $1 \mathrm{~h}$

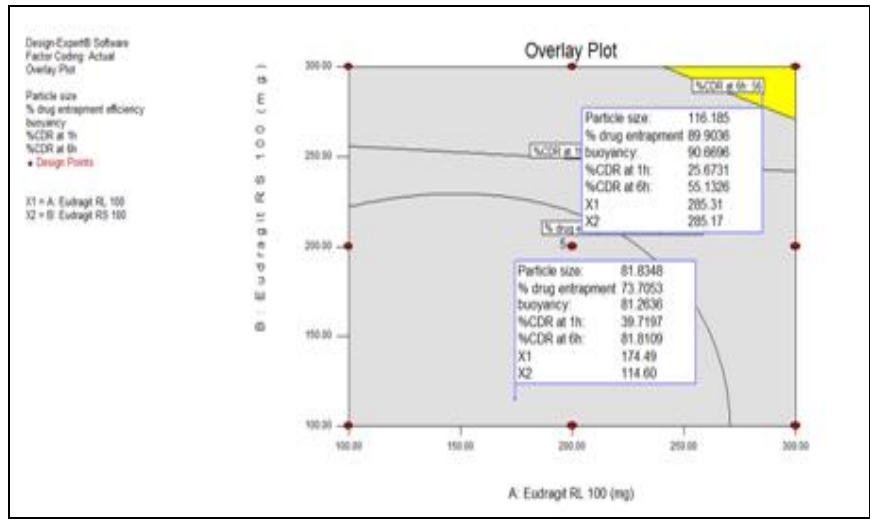

FIG. 14: OVERLAY PLOT OF RESPONSE VARIABLE

TABLE 5: FORMULATION OF CHECKPOINT BATCH

\begin{tabular}{|c|c|c|}
\hline \multirow[t]{2}{*}{ Ingredients } & Batch C1 & Batch C2 \\
\hline & \multicolumn{2}{|c|}{ Quantity taken (mg) } \\
\hline Baclofen & 100 & 100 \\
\hline Eudragit RL100 & 285.31 & 174.49 \\
\hline Eudragit RS100 & 285.17 & 114.60 \\
\hline HPMC K4M & 50 & 50 \\
\hline Mg-stearate & 5 & 5 \\
\hline Acetone & $10 \mathrm{ml}$ & $10 \mathrm{ml}$ \\
\hline
\end{tabular}

HPMC K4m: Hydroxy Propyl Methyl Cellulose 
Verification of Model by Comparing Predicted the comparison of the predicted and actual response Response to Actual Response: Table 6 showing of checkpoint batches.

TABLE 6: PREDICTED RESPONSE AND ACTUAL RESPONSE OF CHECKPOINT BATCH

\begin{tabular}{ccccccc}
\hline Evaluation Parameters & \multicolumn{3}{c}{ Batch C1 } & Batch C2 & \% \\
\cline { 2 - 7 } & $\begin{array}{c}\text { Predicted } \\
\text { value }\end{array}$ & Actual value & \%Error & $\begin{array}{c}\text { Predicted } \\
\text { value }\end{array}$ & Actual value & Error \\
\hline Particle size $(\mu \mathrm{m})$ & 116.81 & 112.21 & 4.09 & 81.83 & 83.56 & 2.07 \\
\% Drug Entrapment & 89.90 & 86.50 & 3.93 & 73.70 & 75.56 & 2.46 \\
\%Buoyancy & 90.66 & 93.21 & 2.73 & 81.26 & 79.23 & 2.56 \\
\% CDR at $Q_{1}(\mathrm{~h})$ & 25.67 & 26.96 & 4.78 & 39.72 & 41.26 & 3.73 \\
\% CDR at $Q_{6}(\mathrm{~h})$ & 55.13 & 53.12 & 3.78 & 81.81 & 84.5 & 3.18 \\
\hline
\end{tabular}

CDR: Cumulative Drug Release

The actual response of the $\mathrm{C} 1$ and $\mathrm{C} 2$ batch was measured and compared with the predicted response of the checkpoint batch. An error was found to be less than 5 of all the responses. Hence, this model was valid, and an optimized batch Table 7 can be selected from the overlay plot of this model.

TABLE 7: OPTIMIZED BATCH

\begin{tabular}{cc}
\hline Ingredients & Quantity(mg) \\
\hline Baclofen & 100 \\
Eudragit RL100 & 297.56 \\
Eudragit RS100 & 278.78 \\
HPMC K4M & 50 \\
Magnesium stearate & 5 \\
Acetone & $10 \mathrm{ml}$ \\
\hline
\end{tabular}

HPMC K4M: Hydroxy Propyl Methyl Cellulose

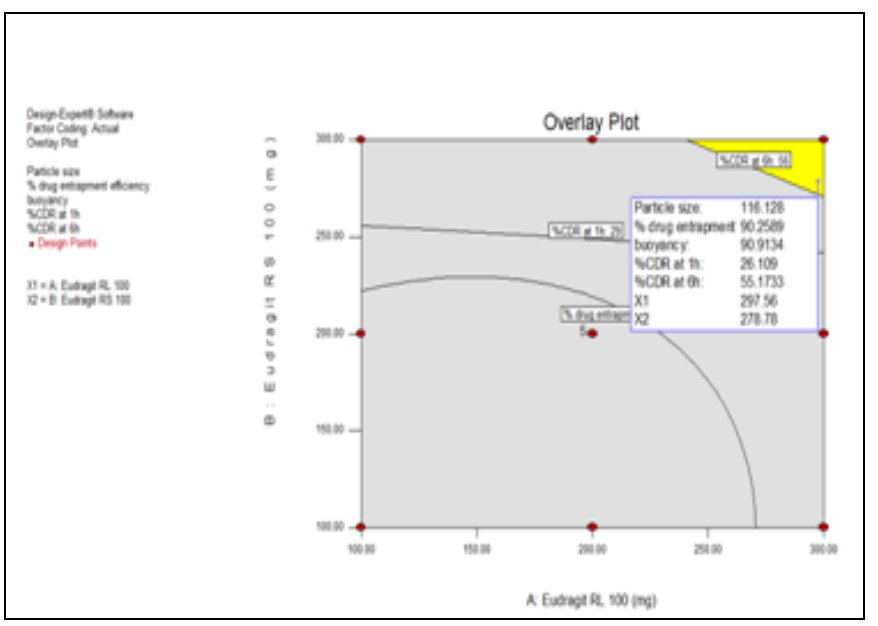

FIG. 15: OPTIMIZED BATCH FROMOVERLAY PLOT
TABLE 8: DISSOLUTION PROFILE OF OPTIMIZED BATCH

\begin{tabular}{cc}
\hline Time $(\mathrm{hr})$ & \% CDR \\
\hline 1 & 25.5 \\
2 & 32.23 \\
3 & 38.59 \\
4 & 42.26 \\
6 & 56.26 \\
7 & 64.35 \\
8 & 72.21 \\
9 & 77.27 \\
10 & 81.15 \\
12 & 85.91 \\
14 & 91.1 \\
16 & 96.01 \\
18 & 98.23 \\
20 & 100.05 \\
24 & 100.15 \\
\hline
\end{tabular}

\%CDR: Cumulative Drug Release

\section{Evaluation of Optimized Batch:}

TABLE 9: PARTICLE SIZE, \% DRUG ENTRAPMENT AND \% BUOYANCY OF OPTIMIZED BATCH
Particle size
$\%$ Drug entrapment
$115.96 \mu \mathrm{m}$
$\%$ Buoyancy
$90.06 \%$
$90.76 \%$

Kinetic Modelling and Mechanism of Drug Release of Optimized Batch: Dissolution profile of optimized batch was fitted to various models, and release data was analyzed on the basis of Korsmeyer- Peppa's equation, Zero-order, firstorder, and Higuchi kinetics ${ }^{15}$ Table 10.

TABLE10: KINETIC MODEL FOR DRUG RELEASE OF OPTIMIZED BATCH

\begin{tabular}{cccccc}
\hline \multirow{2}{*}{ Batch } & Zero-order & First-order & Higuchi & \multicolumn{2}{c}{ Korsmeyer-Peppa's model } \\
& $\mathbf{R}^{\mathbf{2}}$ & $\mathbf{R}^{\mathbf{2}}$ & $\mathbf{R}^{2}$ & $\mathbf{R}^{2}$ & $\mathbf{N}$ \\
\hline Optimized batch & 0.8783 & 0.7715 & 0.9793 & 0.9785 & 0.4857 \\
\hline
\end{tabular}

The best fit model was selected on the basis of relatively high correlation coefficient values. Thus, it may be concluded that from the above data
Higuchi model was followed by formulation. The drug release path was fickian diffusion. 


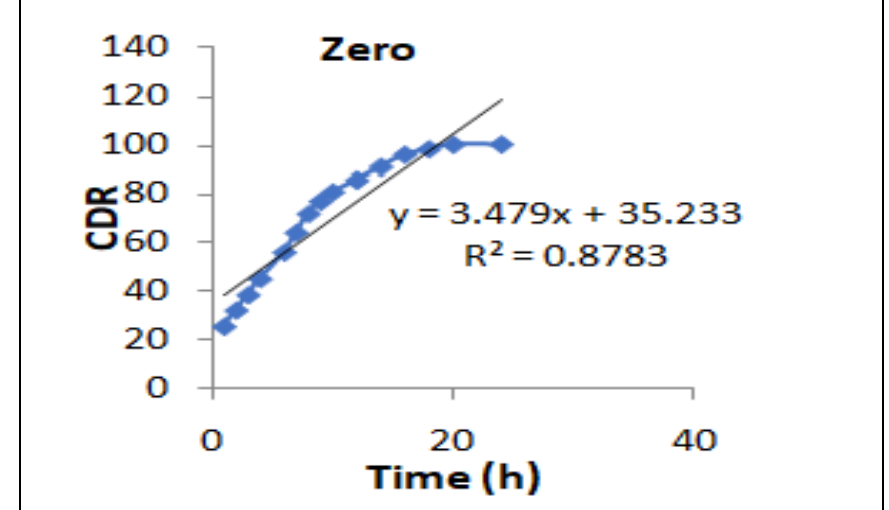

FIG. 16: ZERO ORDER PLOT OF OPTIMIZED BATCHFIG

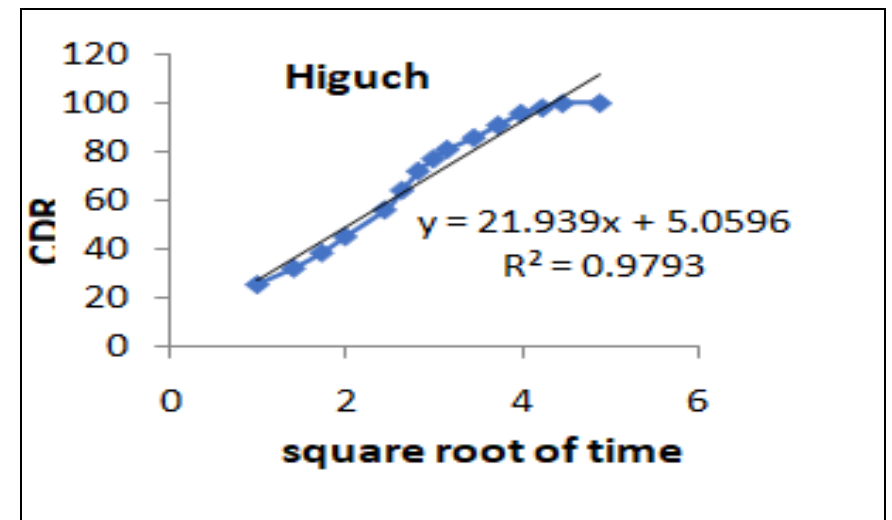

FIG. 18: HIGUCHI PLOT OF OPTIMIZED BATCHFIG

Stability Study of Optimized Batch: A stability study was done to e eth the effect of temperature and humidity (400 $\left.{ }^{\circ} \mathrm{C}, 75 \% \mathrm{RH}\right)$ on floating microspheres during the storage time. Floating

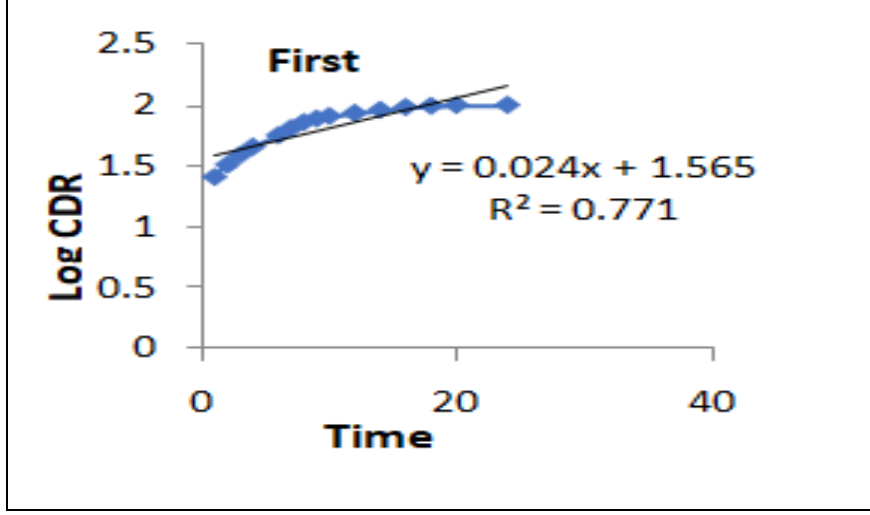

FIG. 17: FIRST ORDER PLOT OF OPTIMIZED BATCH

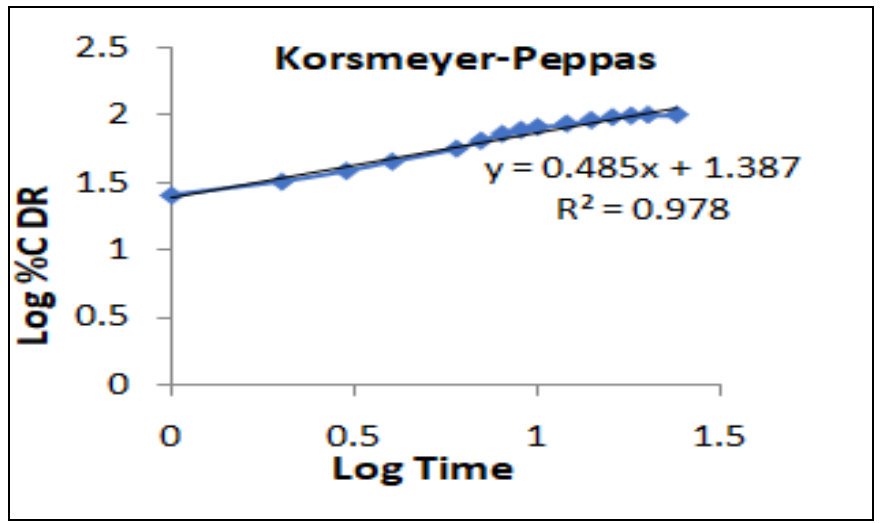

FIG. 19: KORSMEYER-PEPPAS PLOT OF OPTIMIZED BATCH

microspheres were evaluated periodically $(0$ and 1 months) for particle size, $\%$ drug entrapment, $\%$ buoyancy, and in vitro drug release (\% CDR) Table 11.

TABLE 11: EVALUATION OF OPTIMIZED BATCH FOR STABILITY

\begin{tabular}{cccc}
\hline Parameter & Time & Initial & After Stability \\
\hline Particle size & 1 month & $115.96 \mu \mathrm{m}$ & $114.56 \mu \mathrm{m}$ \\
\% Drug entrapment & 1 month & $90.06 \%$ & $90.01 \%$ \\
\%CDR at $\mathrm{Q}_{1}$ & 1 month & $90.76 \%$ & $90.56 \%$ \\
\%CDR at $\mathrm{Q}_{6}$ & 1 month & $25.5 \%$ & $26.01 \%$ \\
\hline
\end{tabular}

\%CDR: cumulative drug release

CONCLUSION: In conclusion, the present study underlines the importance of formulation and evaluation of floating microspheres of Baclofen. Baclofen-loaded floating microspheres were successfully prepared by solvent evaporation technique with having good particle size, yield, entrapment efficiency, buoyancy, and in-vitro drug release. The Baclofen-loaded floating microspheres sustained drug release up to $24 \mathrm{~h}$; thereby, it could be capable of reducing the frequency of administration and the dose-dependent side effects with the repeated administration of conventional baclofen tablets. This type of sustained formulation will be better suitable for spasticity patients. No drug-polymer interaction was found, and formulations remained stable over a long period of time.

ACKNOWLEDGEMENT: The authors are very grateful to Astron PVT. LTD. Ahmedabad to provide gift sample of baclofen to conduct this study.

CONFLICTS OF INTEREST: Authors have no conflict of interest regarding this article. 


\section{REFERENCES:}

1. Sowmya B, Arvapalli S and Gupta AVSSS: A review on Gastroretentive drug delivery system. World Journal of Pharmaceutical and Life Sciences 2019; 5(4): 101-10.

2. Gupta R, Tripathi P, Bhardwaj P and Mahor A: Recent advances in gastro retentive drug delivery systems and its application on treatment of $H$. pylori infections. Journal of Analytical \& Pharmaceutical Research 2018; 7(4): 404-10.

3. Juthi AZ and Bithi TZ: Gastroretentive drug delivery technologies: review. World Journal of Pharmaceutical and Medical Research 2018; 4(2): 11-15.

4. Baviskar P, Patil P and Saudagar RB: Floating drug delivery system: A comprehensive review. Journal of Drug Delivery and Therapeutics 2019; 9(3-s): 839-46.

5. Kandukoori NR, Shanthi MS, Sushma J, Ramya C, Swapna M, Madhu G, Deepika B, Rao KNV and Dutt RK: A review on floating drug delivery system. World Journal of Pharmaceutical Research 2017; 6(5): 553-68.

6. Ghule PN, Deshmukh AS and Mahajan VR: Floating drug delivery system (FDDS): An overview. Research Journal of Pharmaceutical Dosage Forms and Technology 2014; 6(3): 174-82.

7. Dasari N, Enjamuri A and Sudhakar M: Formulation and evaluation of baclofen floating tablets. Asian Journal Research. Pharm. Science 2016; 6(4): 255-60.

8. Gande S and Rao YM: Sustained-release effervescent floating matrix tablets of baclofen: Development, optimization and in vitro-in vivo evaluation in healthy human volunteers. DARU 2011; 19(3): 202-09.

9. Sundar V D, Divya P, Suneendra G and Dhanaraju M D: Design development and evaluation of gastro retentive floating microspheres of atazanavir sulfate. International Journal of Pharmaceutical Sciences and Research 2018; 9(11): 4642- 50 .

10. Sagar B, Singh S K and Jalwal P: Formulation and evaluation of gastro-retentive floating microspheres bearing metformin $\mathrm{HCl}$ for treatment of diabetes mellitus. The Pharma Innovation Journal 2017; 6(10): 173-80.

11. Mishra A, Rathore S, Marothia D and Chauhan CS: Formulation and evaluation of floating microspheres of an anti-diabetic agent. International Journal of Drug Development and Research 2018; 10(2): 7-11.

12. Meghana KJ, Ashok KP, Suresh VK and Manjunath K: Formulation and in-vitro evaluation of floating microspheres of anti-diabetic drug. International Journal of Pharma Research and Health Sciences 2019; 7(3): 300712.

13. Joselin J, Daisy PA, Boby J G, Praveenraj R, Thomas N and Carla B: Formulation and evaluation of floating microspheres of pantoprazole sodium. International Journal of Pharmacy and Pharmaceutical Research 2015; 4(4): 136-47.

14. Kumar KR, Bhikshapathi DVRN and Haarika B: Design \& in-vitro evaluation of floating microspheres using misoprostol. International Journal of Pharmacy and Analytical Research 2017; 6(1): 108-17.

15. Kanteepan $\mathrm{P}$ and Bhikshapathi DVRN: Formulation development and evaluation of pirenzepine floating microspheres. International Journal of Pharmacy and Analytical Research 2018; 7(1): 64-74.

16. Hamdy A, Ossama Y A and Salem H: Formulation of controlled-release baclofen matrix tablets II: Influence of some hydrophobic excipients on the release rate and invitro evaluation. AAPS PharmSciTech 2008; 9(2): 675-83.

17. Subbarao K and Suresh G: Development and evaluation of sustained release floating microspheres containing Ropini- role $\mathrm{HCl}$. International Journal of Pharmaceutical Sciences and Drug Research 2018; 10(3): 158-64.

18. Khairnar G, Naik J and Mokale V: A statistical study on the development of micro particulate sustaineddrug delivery system for Losartan potassium by 32 factorial design approach. Bulletin of Faculty of Pharmacy, Cairo University 2017; 55: 19-29.

19. Khan R, Arora R, Ojha A, Chopra H and Upadhayaya K: Formulation and evaluation of floating microspheres of levofloxacin. International Research Journal of Pharmacy 2018; 9(7): 186-91.

20. Nath B, Nath KL and Kumar P: Preparation and in vitro dissolution profile of Zidovudine loaded microspheres made of Eudragit RS 100, RL 100 and their Combinations. Acta Poloniae Pharmaceutica Drug Research 2011; 68(3): 409-15.

21. Kamalakkannan V, Kumaran AKSG, Babu CS, Muthukumaran T and Raman S V: Preparation and in-vitro evaluation of diltiazem hydrochloride microspheres by using eudragit RL100, eudragit RS100 as polymers. Journal of Chemical and Pharmaceutical Research 2015; 7(5): 1111-20.

22. Patel B, Kushwaha RS and Jain S: Formulation, development and evaluation of floating microsphere of losartan potassium using natural polymer. Journal of Drug Delivery and Therapeutics 2019; 9(3-s): 223-28.

23. Saroja SP and Sudheer P: Formulation and evaluation of aceclofenac mucoadhesive microspheres for oral controlled drug delivery. Asian Journal of Pharmaceutical and Clinical Research 2019; 12(9): 184-90.

24. Purohit K and Garud N: Formulation and evaluation of floating microspheres of losartan potassium using sodium alginate and HPMC by solvent evaporation method. $\mathrm{J}$ of Drug Delivery and Therapeutics 2019; 9(1-s): 60-66.

25. Patil P, Singh $S$ and Sarvanan J: Preparation and evaluation of microspheres of flurbiprofen. International Journal of Pharmaceutical Sciences and Research 2018; 9(12): 5388-93.

26. Bairagee D, Kulkani S, Choudhary $\mathrm{N}$ and Gupta AK: Formulation and evaluation of floating microspheres of amoxicillin trihydrate. International Journal of Pharmacy and Pharmaceutical Research 2018; 11(4): 39-55.

27. Kusuma D, Krishna KSM, Sri J and Sree VS: Formulation and evaluation of floating microspheres of acebutolol. International Journal of Pharmaceutical Sciences Review and Research 2017; 46(1): 31-36.

28. Pandey N, Negi AS and Mahara K: Formulation and evaluation of floating microspheres of nateglinide. International Journal of Pharma Sciences and Research 2016; 7(11): 453-64.

29. Devi AN, Vijendar C, Goud AK, Kumar AD, Khaja M and Anil A: Preparation and evaluation of floating microspheres of cefdinir in treatment of otitis media and respiratory tract infections. J of Pharmaco 2016; 4(3): 1-4.

30. Bhuvaneswari S, Manivannan S, Akshay M and Nify F: Formulation and evaluation of gastroretentive microballoons of acebrophylline for the treatment of bronchial asthma. Asian Journal of Pharmaceutical and Clinical Research 2016; 9(5): 105-11.

31. Ramu S, Suresh $P$, Rao $S$ and Ramakrishna G: Formulation and evaluation of floating microspheres of rosiglitazone. International Journal of Pharmaceutical, Chemical and Biological Sciences 2015; 5(4): 907-18.

32. Sharma P, Garg S and Mann M: Recent advancement in floating drug delivery system and current approaches. World Journal of Pharmacy and Pharmaceutical Sciences 2015; 4(3): 317-41. 
33. Hafeez A, Maurya A, Singh J, Mittal A and Rana L: An overview on floating microsphere: Gastro Retention Floating drug delivery system (FDDS). The Journal of Phytopharmacology 2013; 2(3): 1-12.

34. Dighe D, Choudhary N, Thorat M, Prasad V, Kumbhar M and Singh M: Floating drug delivery system: a novel approach towards gastro retention. International Journal of Pharmaceutical and Chemical Sci 2012; 1(3): 1128-42.

35. Dubey M, Kesharwani P, Tiwari A, Chandel R, Raja K and Sivakumar T: Formulation and evaluation of floating microsphere containing anti diabetic drug. International $\mathbf{J}$ of Pharm and Chemical Sciences 2012; 1(3): 1387-96.

36. Jagtap YM, Bhujbal RK, Ranade AN and Ranpise NS: Effect of various polymers concentrations on physico- chemical properties of floating microspheres. International Journal of Pharmaceutical Sciences 2012; 74(6): 512-20.

37. Singh V and Chaudhary A: Preparation of Eudragit E100 microspheres by modified solvent evaporation method. Acta Poloniae Pharmaceutica ñ Drug Research 2011; 68(6): 975-80.

38. Yadav A and Jain D: Gastroretentive microballoons of metformin: Formulation development and characterization. Journal of Advanced Pharmaceutical Technology \& Research 2011; 2(1): 51-55.

39. Nayak A, Maji R and Das B: Gastroretentive drug delivery systems: a review. Asian Journal of Pharmaceutical and Clinical Research 2010; 3(1): 2-10.

How to cite this article:

Prajapati H, Patel K and Gupta AK: Formulation and evaluation of floating microspheres of baclofen. Int J Pharm Sci \& Res 2021; 12(3): 1482-94. doi: 10.13040/IJPSR.0975-8232.12(3).1482-94.

All @ 2013 are reserved by International Journal of Pharmaceutical Sciences and Research. This Journal licensed under a Creative Commons Attribution-NonCommercial-ShareAlike 3.0 Unported License.

This article can be downloaded to Android OS based mobile. Scan QR Code using Code/Bar Scanner from your mobile. (Scanners are available on Google Playstore) 